\title{
Lichens of the Hassan Tower Monument (Rabat, Morocco)
}

\author{
Ilham Nattah', Amina Ouazzani Touhami', Rachid Benkirane', Mohamed El Kortbi², and Allal \\ Douira' $^{1}$ \\ ' Laboratory of Botany and Plant Protection, University Ibn Tofail, Faculty of Sciences, P. O. Box 133, 14000 \\ Kénitra, Morocco; ${ }^{2}$ Laboratoire des Matériaux et Génie Civil, Université Hassan II, Casablanca, Morocco
}

Received: August 22, 2011 / Accepted: February 1, 2012

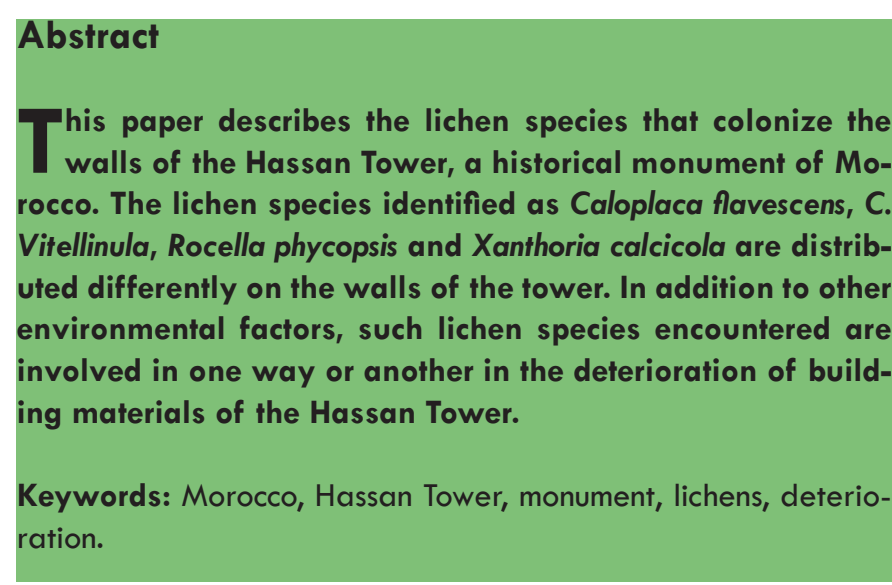

\section{Introduction}

The Imperial city of Rabat (capital city of Morocco) hosts famous monuments built during the Almohad era (1128 to 1269AD). The Hassan Tower, Oudayas, Chellah, are some notable examples of the Arab-Islamic architecture of the XII-XIII centuries. Hassan Tower is a symbolic feature representing the city (El Azhari, 2009).

According to Caillé (1954), Hassan Tower is the minaret of an incomplete mosque in Rabat. The construction of the tower in 1195 AD, was intended to be the largest minaret in the world along with the mosque. In 1 199, Sultan Yacoub Al-Mansour died and the construction on the mosque stopped. At the time, the tower only reached $44 \mathrm{~m}$, about half of its intended $86 \mathrm{~m}$ height. Instead of stairs, the tower is provided with ramps which would have enabled the muezzin to ride a horse to the top of the tower to call for prayers.

The tower, made of red sandstone along with the remains of

* Corresponding author: douiraallal@hotmail.com the mosque and the modern Mausoleum of Mohammed V, forms an important historical and tourist complex in Rabat.

The historical monuments of Rabat show many signs of weathering. The scientific works on the weathering process of these monuments all agreed that the causes of deterioration are anthropogenic origin (Bellitir 1987, Alaoui et al., 2006, Zaovia et al., 2006, Asebriy et al., 2007, 2009). The climate of Rabat is characterized by high humidity and high salt content of marine origin. Added to climatic, the exhausts of vehicles on the arterial roads of the city induce further deterioration (El Azhari, 2009). Lichen species also play an important role in the process of deterioration of a wide range of building materials. This is attribute to their capacity to grow on a variety of substrate under a wide range of environmental conditions (Nimis et al., 1987, 1996). The present work focuses on lichens of Hassan Tower.

\section{Materials and Methods}

The study of the lichens involved their identification both in the field and in the laboratory. The lichen samples collected from the walls of Hassan Tower were examined using light microscopes. Free-hand sections were made using a razor blade and mounted in water and cotton blue. Tissue and ascospore measurements were made in water. Granulation of tissues was observed in polarized microscopes. Spot test reactions of thalli, apothecial margins, medulla and discs were tested with the standard reagents, Potassium hydroxide 10\% (K) and Sodium hypochlorite (C). A comparison was then made with the information available in various analytical keys and guides (Harmand, 1913; Wade, 1965; Mayrhofer and Poelt, 1979; Steiner and Poelt, 1982; Laudon, 1992; Arup, 1994; Wetmore and Karn- 
felt, 1998; Lindblom et al., 2005; Soun and Vondrak, 2008; Gaya et al., 2008). The specimens are kept in the herbarium of the Laboratory of Botany and Plant Protection, Faculty of Sciences, University Ibn Tofail, Kénitra, Morocco.

\section{Results}

The results of this study showed the presence of four lichen species: Caloplaca flavescens, Caloplaca vitellinula, Roccella phycopsis and Xanthoria calcicola detailed as follows:
- Caloplaca flavescens (Huds) Laundon: Thallus crustose, forming closely adpressed rosettes, yellow to orange up to $1-2 \mathrm{~cm}$ in diameter. Rosettes of thalli single or grouped, whitish at the centre which often disintegrates and falls out with age (Fig. 1 A). Lobes at the margin of thallus $0.5-1.5 \mathrm{~mm}$ long and $1 \mathrm{~mm}$ wide, convex and sometimes overlapping. Cortex present and a continuous layer visible in polarized light (Fig. 1C). Apothecia up to $0.8-1 \mathrm{~mm}$ in diameter, orange, mainly confined to the centre of the thallus; disc flat to convex. Spore broad, lemon, up to 10 $\mu \mathrm{m}$ long and $6 \mu \mathrm{m}$ wide (Fig. 1E), 8 per ascus (Fig. 1D). Reac-
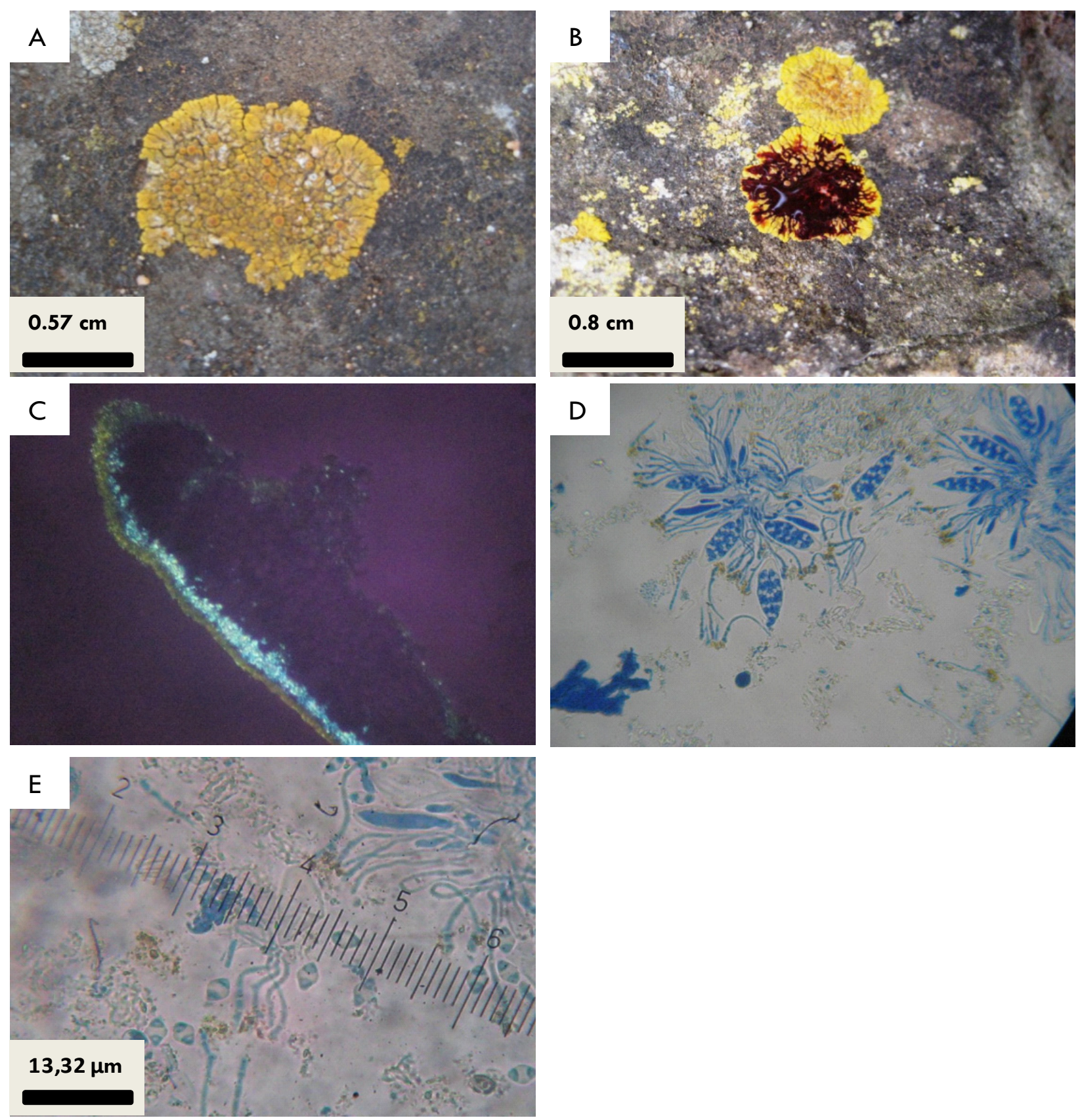

Figure 1. Caloplaca falavescens: Thallus (A), $\mathrm{K}^{+}$: red- purple (B), thallus transversal section visualized under polarized light (C), Ascus (D), spore (E). 
tions of thallus and apothecia $\mathrm{K}^{+}$: red - purple. (Fig. 1B). Habitat: saxicolous on earth of the Hassan Tower.

- Caloplaca vitellinula (Nyl.) H. Olivier: Thallus crustose, reduced to little orange-yellow granules (Fig. 2A). Apothecia yolk; they are rare or sometimes many, scattered or grouped in the center of the thallus; they are large below $0.5 \mathrm{~mm}$, thin margin, the disc more or less covex, epithecium golden yellow. Paraphyses simples to branched, with the top, 2 or 3 short articles and unevenly swollen (Fig. 2C). Ascus ellipsoids; spores 8 per ascus, polaribilocular, ellipsoid, hyalines, sometimes very close together in boxes, spores $8.9 \mu \mathrm{m}$ long $5.49 \mu \mathrm{m}$ wide (Fig. 2D). Test color: $\mathrm{K}^{+}$: red-purple (Fig. 2B). Habitat: saxicolous on the tower's wall. - Rocella phycopsis (Ach.) Ach.: Thallus fruticulose, up to $5 \mathrm{~cm}$ long, grey branches round or slightly compressed, 1 to $2 \mathrm{~mm}$ thickness, smooth, pruinose, subsimple or dichotomously divided (Fig. 3A, 3B and 3C); medulla of the spike yellow (Fig. 3E); soralia many, whitish, tubercled to globose; apothecia absent. Cortex: $C+$ red (Fig. 3D) then turns into orange, then yellow and disappears; medulla and soralia $\mathrm{C}-, \mathrm{KOH}$-. Habitat: saxicolous on the Tower's wall of Hassan (substrate type: calcarenite).

- Xanthoria calcicola Oksner: Thallus foliose, rigid, up to $3 \mathrm{~cm}$ long, upper side yellow orange, granular, warty (presence of large convex isidia towards the center of thallus), underside simple white rhizines; lobes overlapping and corrugated (Fig.
4A). Apothecia scarce or absent; disc orange, $0.8 \mathrm{~mm}$ across with, frequently notched warty edge; Ascus spores, hyaline, polariloculaire, up to $10.82 \mu \mathrm{m}$ long and $6.82 \mu \mathrm{m}$ wide (Fig. $4 \mathrm{C}$ ). Test color: $\mathrm{K}^{+}$: red- purple (Fig. $4 \mathrm{~B}$ ). Habitat: saxicolous on the tower's wall.

\section{Discussion and Conclusion}

Calcareous stones, known as beige calcarenite ("Stone of Salé"), plio-quaternary age (El Azhari, 2009), were used in the construction of the Hassan Tower. The calcarenite is richer in quartz grains and shows a very high porosity (EL Amrani, 2009). The high porosity of the rock salt facilitates the infiltration of fluids whose speeds are altered (El Azhari, 2009). This process of rock weathering facilitates the development of some lichen species (Kofler, 1954).

The lichen species found on this monument are calcicolous. They were reported in the north-west and central region of Morocco (Egea, 1996; Alonso and Egea, 1997). They were not described and sometimes their substrates were not specified. many factors (historical, topographic, temporal, access, edaphic, climatic, ecological) influence the establishment of mural vegetation. However, Lisci et al. (2003) reported that the distribution of the encountered lichen species depends on humidity. Roccella
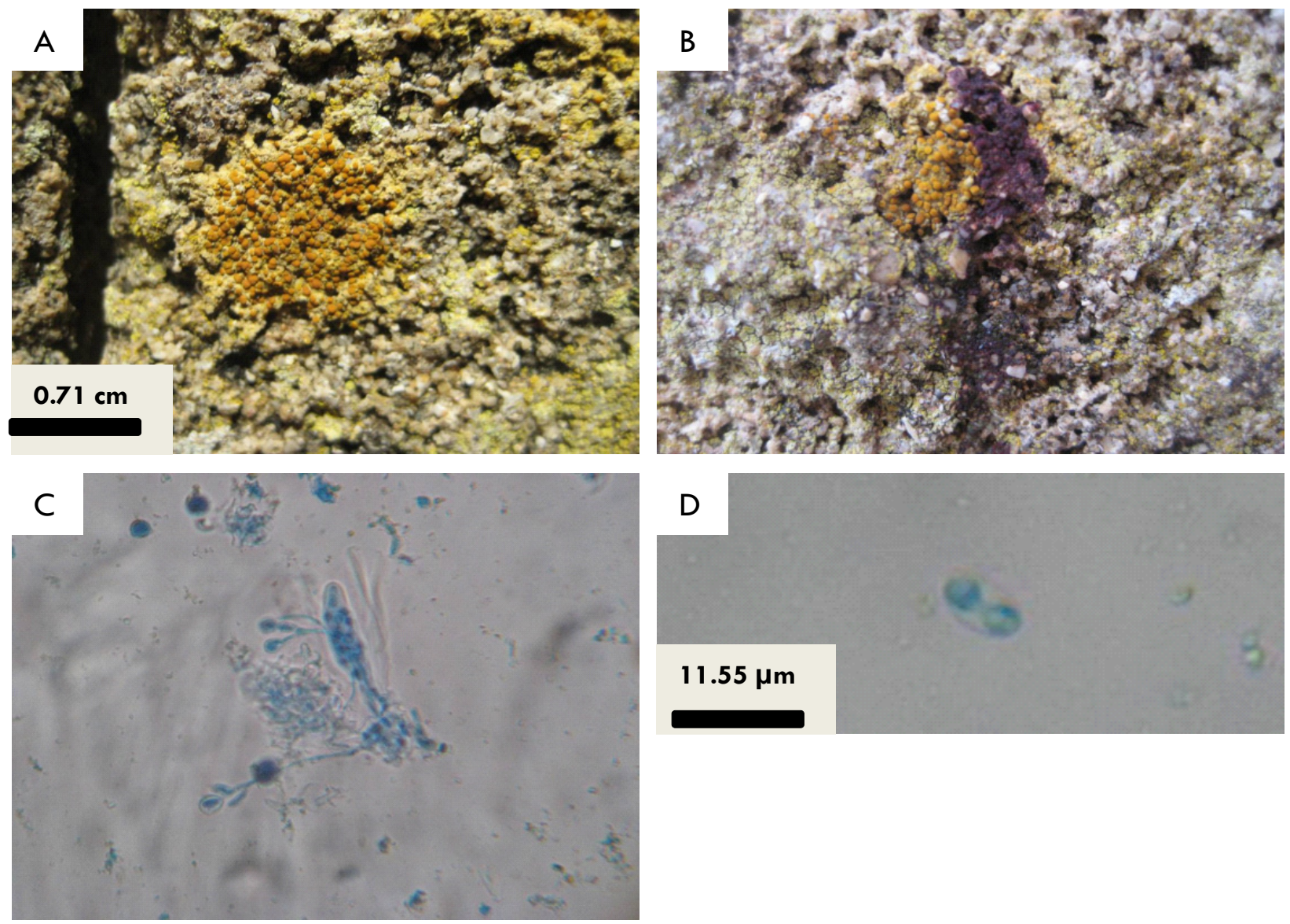

Figure 2. Caloplaca vitellinula: Thallus attached to the wall Tower Hassan (A), K+: red purple (B), paraphyse (C), spore (D). 

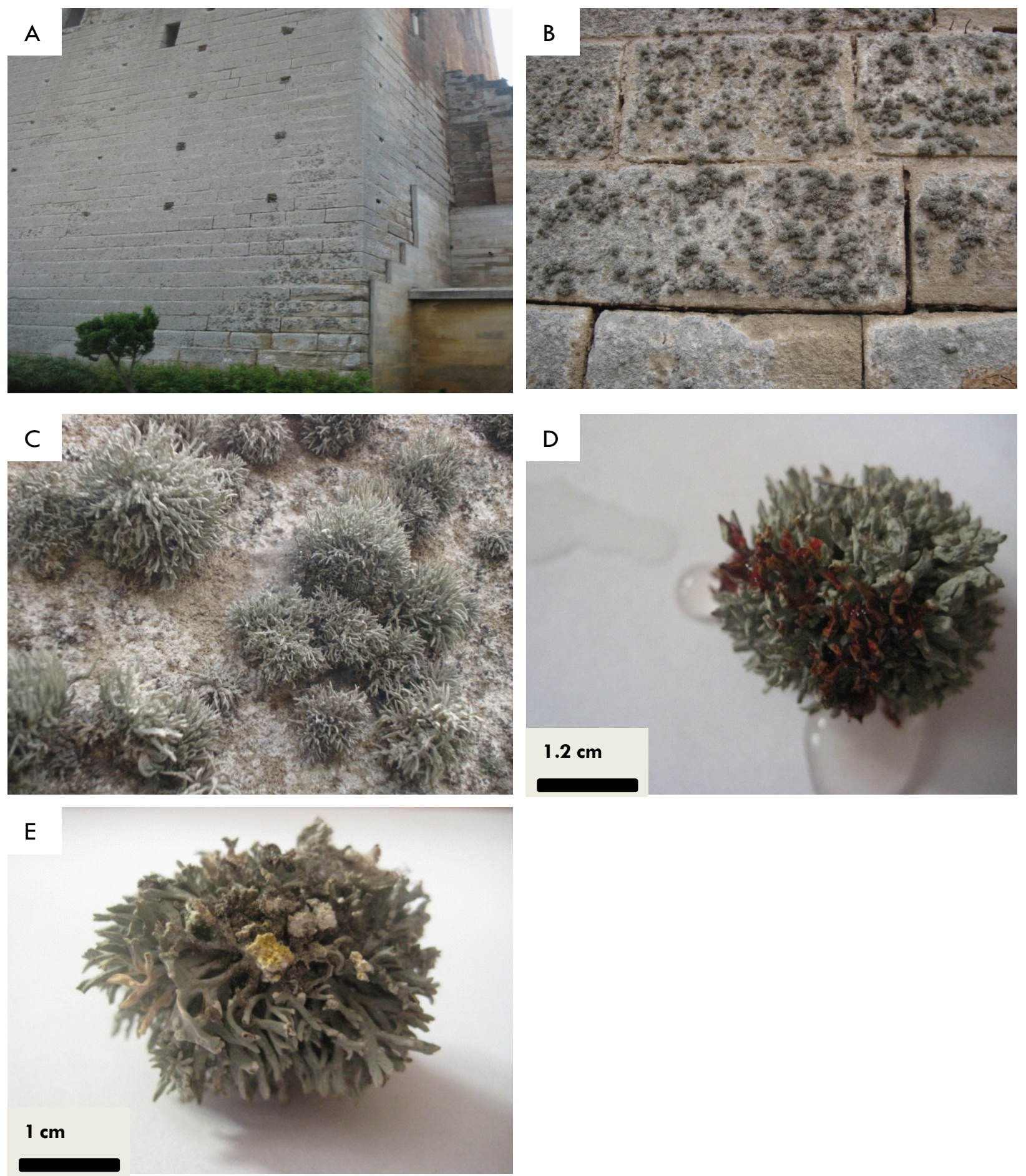

Figure 3. Roccella phycopsis: Thallus attached to the wall Tower Hassan (A), (B) \& (C), Spot test reaction of thallus $C+$ : red (D), medulla of the spike: yellow (E).

phycopsis represents the most abundant species. It is very common on the exposed face northwest of the tower and covers several meters above the ground. Rocella phycopsis is almost always fixed vertically to the substrate (Lisci et al., 2003). In Morocco this species was reported by Alonso and Egea (1997) on Pistacia lentiscus (Al Hoceima), Tetraclinis articulata (Dar-Mter) and Arga- nia spinosa (Agadir)

Caloplaca vitellinula is less abundant and forms an association with Rocella phycopsis whereas Caloplaca flavescens abounds on the cement ground near the tower. The latter is considered as more frequent not only on pure limestone but also on other calcareous or alkaline rocks and artificial substrata such as con- 

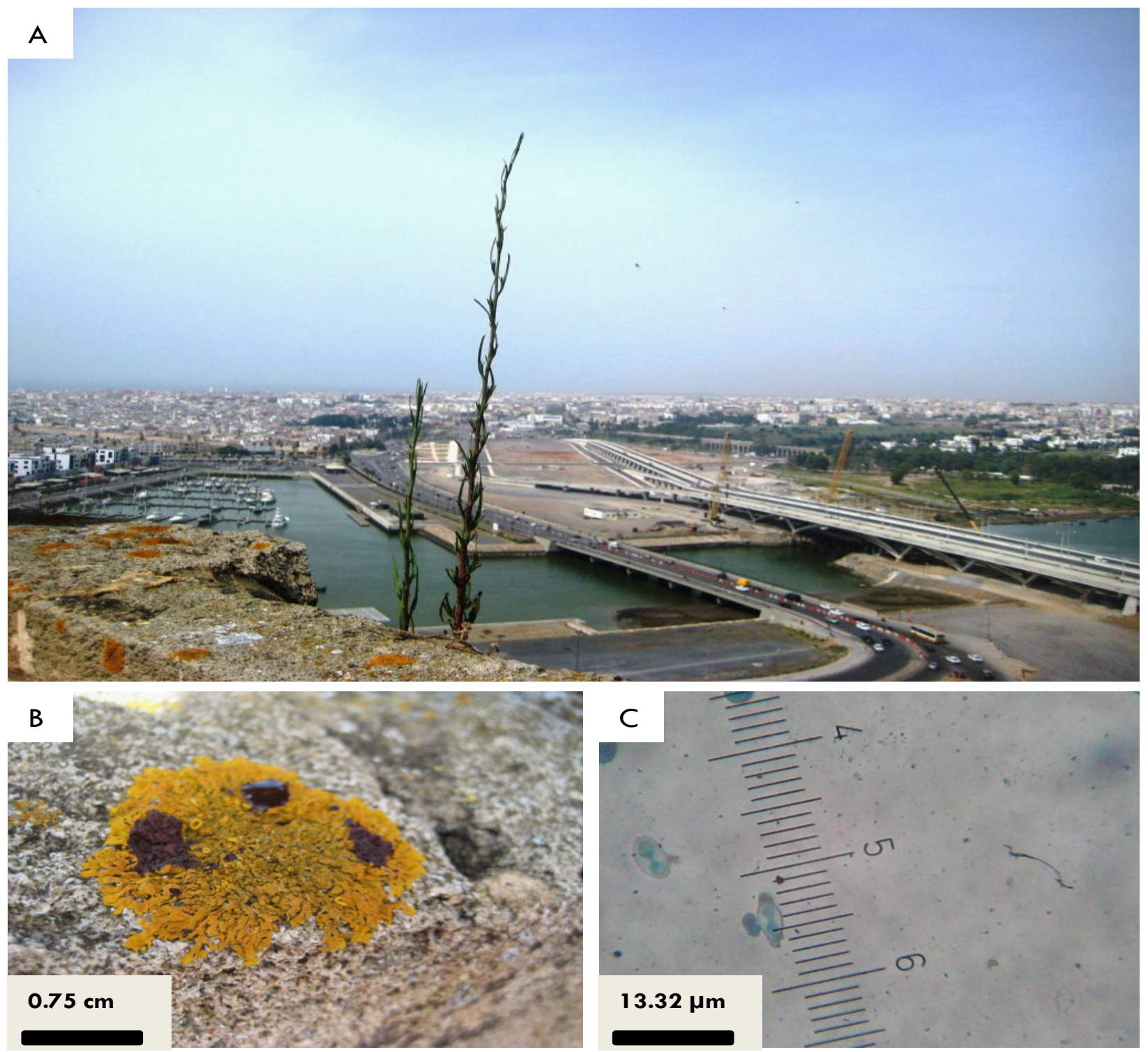

Figure 4. Xanthoria calcicola: Thallus attached to the wall Tower Hassan (A), K+: red-purple (B), spore (C).

crete, mortar, roofing tiles and monuments but very rarely on the dusty bark of trees near quarries (Laundob, 1992).

Xanthoria calcicola colonizes the walls of the terrace of the tower. It was reported on calcarenite rocks (Anonymous, 2005) accompanying Rocella phycopsis (Kinalioglu, 2007) and is well known for its accumulation of trace metal at high ratio (Uluoglo et al., 2007).

Although lichens are excellent atmospheric pollution bioindicators (Rigamonti, 2008). They may produce much worse damage, such as major alterations of stone surfaces through biogeophysical and biogeochemical processes. Biogeophysical alterations are caused by the penetration of fungal hyphae beneath the stone surface and by the contraction and expansion of the lichen subsequent to desiccation and rehydration (Seaward, 1988). The chemical alterations lichens produce are due to three substances they secrete (Nimis, 2001) which carbon dioxide, li- chen compounds with complex properties, and oxalic acid carbon.

In fact, according to Rigamonti (2008), if on the one hand lichens can be considered as being a disturbance that must be eliminated because chemical-physical deterioration and chromatic alteration that some species cause. On the other hand, following a naturalistic approach, they can act as a useful indicator as to the condition of the place.

\section{References}

Alaoui M, L Asebriy, C Bucci , El El Amrani, R Franchi, F Guerrera, M Martin Martin, C Patamia, G Raffalli, MP Robles, J Tejera de Leon, and L Tentoni (2006) GIS and new technologies in geological analysis for restoration of Islamic monuments of the city of Rabat (Morocco). 5th European Congress on Regional Geoscientific Cartography and Earth Information and Systems Water, Barcelona, Catalonia, 
Spain, June 13-16.

Anonymous ( 2005) www.mousses-lichens-haut-languedoc.org/Xanthoria_calcicola.htm.

Alonso FL and JM Egea (1997) Líquenes epifíticos de algunas localidades costeras de Marruecos. Acta Botanica Malacitana 22: 13-18.

Arup U (1994) The Genus Caloplaca on Seashore Rocks in Eastern North America. The Bryologist 97 (4): 377-392.

Asebriy L, C Bucci, I El Amrani, R Franchi, F Guerrera, M Martin Martin, C Patamia, G Raffaelli, P Robles Martin, J Tejera de Leon, and L Tentoni (2007) Étude Intégrée de la dégradation des monuments historiques Romains et Islamiques de la ville de Rabat (Maroc): Proposition de solutions durables de prévention et restauration. Science and Technology for Cultural Heritage 16 (1-2): 45-65.

Asebriy L, C Bucci, TE Cherkaoui, El EL Amrani, R Franchi, F Guerrera, M Martin Martin, C Patamia, G Raffaelli, P Robles Marin, J Tejera de Leon, and FJ. Alcala (2009) Deterioration processes on archaeological sites of Chellah and Oudayas (world cultural heritage, Rabat, Morocco): restoration test and recommendations. Ital. J. Geosci., 128 (1): 157-171.

Bellitir D, R Nijs, L Asebriy, and M Aberkane (1987) Evolution de la calcarénite dans les constructions, vitesse d'altération en fonction des facteurs naturels et industriels. Mines, Géologie \& Énergie 57: 83-88.

Caillé J and J Hainaut (1954) La mosquée de Hassan à Rabat. Publications de l'Institut des Hautes Etudes Marocaines. Erik Hanson books and Ephemera, San Diego, CA, USA, pp. 172.

Egea JM (1996) Catalogue of lichenized and lichenicolous fungi of Morocco. Bocconea 6: 19-114.

El Azhari H, and IE El Amrani El Hassani (2009) Diagnostic and Monitoring of building stones using $\mathrm{P}$-wave velocity: application to historical monuments of Rabat (Morocco). In: Ferrari A (ed.): Proceedings of the 4th International Congress on "Science and technology for the safeguard of cultural heritage in the Mediterranean basin", Cairo, Egypt, 6th-8th December 2009, vol. II, session B, pp. 487-494.

El Amrani El Hassani IE, and H El Azhari (2009) Evaluation des propriétés physico-mécaniques des pierres de construction du Maroc à partir des vitesses des ondes $\mathrm{P}$ et de la résistance du Maroc. Bulletin de I'Institut Scientifique, Rabat, section Sciences de la terre 31: 41-54.

Gayae E, P Navarro-Rosinés, X Llimona, N Hladun, and F Lutzoni (2008) Phylogenetic studies on the Teloschistaceae (lichen-forming Ascomycota, Lecanoromycetes). Mycol. Res. 112 : 528-546.

Harmand J (1913) Lichens de France. Catalogue systématique et descriptif. Crustacés. Pannariés, heppiés, lécanorés, pertusariés, thélotremés. L. Lhomme édit., Paris, pp. 761-1185.
Kinalioglu K (2007) Lichens of the alpine region in Arakli- Sürmene District, Trabzon Province (Turky). Cryptogamie Mycol 28 (2): 159168.

Laundon JR (1992) Caloplaca Th. In: Purvis OW., BJ Coppins, DL Hawksworth, PW James and DM Moore (ed.), The lichen flora of Great Britain and Ireland, pp. 141-159.

Lindblom L, MH Ladstein, HH Blom, S Ekman, and E Timdal (2005) Xanthoria aureola in Norway and a key to the species of Xanthoria s. str. in Scandinavia. Graphis Scripta 17: 12-16.

Lisci M, M Monte, and E Pacini (2003) Lichens and higher plants on stone: a review. International Biodeterioration \& Biodegradation 51 (1): 1-17.

Mayrhofer H, and J Poelt (1979) Die saxicolen Arten der Flechtengattung Rinodina in Europa. Bibliotheca Lichenologica 12: 1-186.

Nimis PL, D Pinna and O Salvadori (1996) Licheni e Conservazione dei monumenti. Clueb ed., Bologna, pp. 165.

Nimis PL, M Monte, and M Tretiach (1987) Flora e vegetazione Lichenica di aree archeologiche del Lazio. Studia Geobotanica 7: 3-161.

Nimis PL (2001) Artistic and Historical Monuments: Threatened ecosystems. In Frontiers of Life, Part 2: Discovery and Spoliation of the Biosphere, sect. 2: Man and the Environment. San Diego: Academic Press, S Diego, pp. 557-569.

Rigamonti M (2008) Experimental Ecology and Geobotany Lichens and monuments: searching for the balance between the necessity of restoration and preservation, and the improvement of the naturalisticenvironmental aspects of the historical-architectural heritage. Scientifica Acta 2 (2): 93-96.

Seaward MRD (1988) Lichen damage to ancient monuments: a case study. Lichenologist 20 (3): 291-295.

Šoun J, and J Vondrák (2008) Caloplaca aurantia and Caloplaca flavescens (Teloschistaceae, lichen-forming fungi) in the Czech Republic; with notes to their taxonomy and nomenclature. Czech Mycology 60: 275-291.

Steiner M and J Poelt (1982) Caloplaca sect. Xanthoriella sect. nov.: Unterschungen über die "Xanthoria lobulata Gruppe "( Lichenes, Teloschistaceae). PI. Syst. Evol. 140: 151-177.

Uluozlu OD, K Kinalioglu, M Tuzen, and M Soylak (2007) Trace metal levels in Lichen samples from Roadsides in East Blak Sea Region, Turkey. Biomedical and Environmental Sciences 20: 203-207.

Wade AE (1965) The Genus Caloplaca Th Fr. In the Britsh Isles. The Lichenologist 3: 1-28.

Wetmone CM, and El Kärnefelt (1998) The lobate and subfruticose species of Caloplaca in North and Central America. The Bryologist 101 (2): 230-255. 